\title{
REVIEW
}

\section{TISSUE DONATION AND TRANSPLANTATION PROGRAM IN SRI LANKA \\ A Medico-legal point of view}

\author{
Vadysinghe A.N ${ }^{1}$, Dassanayaka P.B ${ }^{2}$, Edussuirya D.H ${ }^{3} \&$ Rukshana M.J.F ${ }^{4}$ \\ ${ }^{1,3,4}$ Department of Forensic Medicine, Faculty of Medicine, University of Peradeniya, \\ Sri Lanka \\ 2JMO"s Office, Colombo South Teaching Hospital, Kalubowila, Colombo, Sri Lanka \\ Corresponding Author: Vadysinghe A.N \\ E-mail: amal_vadysinghe@yahoo.com ～(iD) https://orcid.org/0000-0002-1994-7830
}

\begin{abstract}
Tissue donation and organ transplantation plays a key role in the management of the critically ill patient.

The harvesting of organs for transplantation is done according to the legal framework of the country and based on circulars, protocols and guidelines of health and legal authorities. Clear knowledge regarding medico-legal issues and ethical aspects are mandatory for an effective transplantation program.

The authors attempt to critically evaluate the medico-legal and ethical aspects pertaining to the existing system for tissue donation and transplantation in Sri Lanka and compare the local provisions with those existing in other countries. It is envisaged that this would enable identification of amendments required.
\end{abstract}

Keywords: Tissue donation, Organ transplantation, Medico-legal aspects, Ethics, Living donation

All articles in Sri Lanka Journal of Forensic Medicine, Science \& Law are licensed under the terms of the licensed under a Creative Commons Attribution-Non Commercial 4.0 International License. 


\section{INTRODUCTION}

Even though transplantation is life-saving therapy for end stage organ failure only about $10 \%$ of the global need is met. ${ }^{1,2}$

Each day, about 60 people around the world receive an organ transplant, while 13die due to non-availability of organs. ${ }^{3}$ The World Health Organization (WHO)' reports that the majority of transplanted organs across the world are from live donors. In UK, the annual number of live donors is equal to that of dead donors. In most developing countries, almost all kidney transplants are from live donors. In the year 2017, around 400 kidney transplantations had been done in Sri Lanka, while more than 2000 patients had died due to renal failure while awaiting transplantation. ${ }^{4}$ Approximately, 34,768 organ transplantations had been done in United States in 2017..$^{5}$ While the approximate ratio of organ transplantation per total population is 1: 9,408 in USA it is 1: 52,477 in Sri Lanka.

There is a significant gap between supply and demand of organs which has resulted in long waiting lists for organ transplantation. In Sri Lanka this organ shortage is mainly due to a trend towards living rather than cadaveric organ retrieval. Medical officers have been appointed at national and local level by the Ministry of health in Sri Lanka to coordinate the national transplantation program effectively. They coordinate both live and cadaveric donations in varying capacities (eg., talking to recipients and donors, coordinating the process etc.). However, it appears that the involvement of nongovernmental organizations with the national program is significantly less than that of other developing countries like India. Reviewing the current program intermittently and on regular basis, identification of issues and addressing them accordingly with input from international stakeholders are mandatory to achieve a successful organ transplantation campaign locally.
Recent advances in the field of transplant surgery along with significant improvements in the quality of the life after transplantation, has resulted in an increasing trend towards organ transplantation among end stage organ failure patients in Sri Lanka. However, it is associated with medico-legal and ethical dilemmas and controversies. One such issue related to retrieval of organs for transplantation is the point at which retrieval should be done; whether after brain stem death or after whole brain death.

In Sri Lanka, the Transplantation of Human tissues (THT) act No 48 of 1987 (certified on $11^{\text {th }}$ December 1987) and the Director General Health (DGHs) circulars of Ministry of health on organ Transplantation lay down procedures for the donation and removal of human bodies, organs and tissues for therapeutic, scientific, educational and research purposes. However, there are differences in interpretation and contradictions between the currently practiced laws in Sri Lanka and those of other countries. Clear knowledge regarding this aspect among medical practitioners will help the organ transplantation team to retrieve high quality organs from potential cadaveric and live donors. When organs are transplanted according to a prescribed medico-legal and ethical framework, it would reduce the risks to the live donors, may save valuable human lives and result in an effective transplant program in Sri Lanka.

\section{Living donations}

A living donation takes place when a person donates an organ to another whilst alive. ${ }^{6}$ Around 6000 living organ donations are being reported each year in USA. ${ }^{7}$

Most living donations happen among family members or between close friends. People who choose to donate to unknown persons are considered as altruistic living donors. Organs or tissues that can be donated during 
life are either paired organs (eg, kidneys) or regenerative tissue (liver, lung, pancreas, intestine). ${ }^{8}$

In cases where living organ donors are genetically related to the recipient there is a considerable risk of the recipient acquiring genetically related disorders later in life due to shared inheritance of genetic variants or common environmental exposure that increases susceptibility to organ failure. ${ }^{9}$ Related living kidney donors are at higher risk of end-stage renal disease compared with unrelated living kidney donors. ${ }^{9}$

Living organ donations have several ethical considerations. During transplantation, the transplantation surgeon may endanger the life of a healthy individual to save the life of the patient. Therefore some argue that living donation should be abandoned. ${ }^{10}$

Therefore in cases where it is necessary to retrieve organs from live donors for transplantation, the following aspects/guidelines should be adhered to by medical practitioners. ${ }^{11}$

1. Ensure that there is a reasonable prospect of the transplant being successful. If prospects of success are remote transplantation should not be carried out despite consent for donation.

2. Ensure that benefit to the recipient far outweighs the likely detriment to the donor.

3. Ensure that the donor is capable of providing valid consent (free /voluntary/well informed / written / witnessed).

4. Do not encourage a potential donor to donate organs.

5. In case of paired organs, make sure that the other organ is healthy and will sustain life of the donor with minimal handicap.

6. No consent must be obtained nor valid for the donation of organs essential for the life of the donor (eg: removing the large part of a regenerative organ risking the donor).
If a donor experiences an adverse effect it would have a negative impact on the entire transplant team and the institution. In order to avoid such repercussions the transplantation procedure should take place according to precise criteria and the law of the country. Therefore donors should be treated in a respectable manner without compromising principles of autonomy and beneficence and keeping in mind the principle of non-maleficience. In cases of legal consequences the donor could be a witness and could provide evidence in court.

\section{Donations upon death}

A person will be considered dead if he has experienced an irreversible cessation of spontaneous respiratory and circulatory functions. However in the event that life is supported by artificial means, a person will be considered dead if he has experienced an irreversible cessation of spontaneous brain functions. ${ }^{12}$

Although donations of organs/tissues upon death is rare (except corneal donations), it is practiced in Sri Lanka. According to the Transplantation of Human Tissue Act of 1987, any person above the age of twentyone years may consent in writing to the donation, to take effect upon his death, of his body or any part thereof or any tissue. Such consent given during life should not have been revoked thereafter. In cases where the deceased has not given prior consent for a donation effective upon death, it shall be lawful for the next of kin of such deceased person, who is above the age of twenty-one years to give consent, if the deceased during life has not objected to donation. ${ }^{13}$

Although persons above the age of twentyone years can donate their organs according to the law of many countries including Sri Lanka, age is a known factor that influences the success of transplantations. Transplantation of liver from the individuals above the age of 55 years $^{14-17}$ or renal transplants from individuals more than 65 years have shown a higher failure rate than donations from younger individuals. ${ }^{18,19,20}$ 
It has been reported that with increasing age, the number of organs discarded increases. $^{21}$

Harvesting good quality organs from cadavers under the prescribed manner according to the law of the country helps to save valuable human lives.

Road traffic accidents, suicides and homicides leads to brain death of individuals due head injuries, leaving potential organ donors. $^{22}$ In 2016, 3003 deaths occurred due to road traffic accidents and 502 deaths due to homicide in Sri Lanka. ${ }^{23,24}$ Majority of victims were young or middle aged. Suicide has been a leading cause of death in the 16 to 24 year age group while homicide was a leading cause of death in those between 21 to 40 years of age. ${ }^{25,26}$ When considering homicides in Sri Lanka, it has been identified that the common regions affected are chest and head. ${ }^{26}$ These victims are potential kidney, bowel, pancreas and liver donors. If consent had been given by them for organ donation previously or if their next of kin consents for organ donation the requirement for living donations would be less. Where the circumstance of death is "unnatural", the criminal procedure code of Sri Lanka dictates that the release of bodies are subjected to an inquest followed by autopsy examination. ${ }^{27}$ Even though this is a traumatic time for the relatives there is an important duty with the medical practitioner to confirm death, arrange for a postmortem examination and consider the possibility of organ donation. If a recognized data base of potential donors or a donor card system exists, the retrieval of tissues upon death could be done without undue delay. It is timely that we institute such a process to help expedite the process of harvesting of organs from the dead.

\section{Process of Organ retrieval for organ transplantation in medico-legal cases}

In Sri Lanka, under the provisions of the criminal procedure code, release of the dead body in a medico-legal investigation is subject to an inquest followed by autopsy examination. ${ }^{4}$ After brain death is confirmed and when consent has been obtained for retrieval of organs for transplantation, the JMO on duty and the coroner will be informed as such in writing. The coroner has to authorize organ retrieval by the transplantation team in the presence of the $\mathrm{JMO}$, who is part of the team. It is mandatory that the JMO documents the details of the procedure and submit a report thereafter. Further, the organ retrieving surgeon will provide a comprehensive report regarding the procedure carried out, findings and the condition of the retrieved organs in accordance with the guidelines provided in the DGHS Circular No: 01-37/2010. This report which should include the following information is essential for subsequent medico-legal procedures.

a) Details of the deceasedName/Age/gender/ address/Bed Head Ticket number

b) Date, time and place of the procedure

c) Name of the organ/s

d) Side of the organ ( e.g. Left /Right)

e) Weight of the organ/s

f) Size of the organ retrieved

g) Macroscopic appearance

h) Surgical procedure with details of the incisions and date/time and name/s of the transplant team

i) Color photograph of the organ with a scale (preferable).

The JMO who conducts the autopsy subsequent to harvesting at the request of the ISD/Magistrate, will attach the report submitted by the surgeon who has retrieved the organs along with the formal autopsy report. $^{4,13,27}$

The current practice in Sri Lanka with regard to organ retrieval from a victim of violence on artificial life support who is deemed brain dead (beating heart cadaver) is to obtain a magisterial order for organ removal by forwarding a " $\mathrm{B}$ " report to court through the investigating police officer or a lawyer of the transplantation team. However, sometimes organ removal and transplantation takes place with the 
concurrence of the JMO and inquirer with assistance of the investigating police officers. Therefore, specific guidelines for retrieval of organs from persons who are brain dead need to be streamlined.

Difficulties are also encountered when victims of violence are transferred from distant health units under the jurisdiction of different police and court areas and may result in delay. This delay while providing relatives the time to think about donation may also result in withdrawal of consent. It is further complicated if the victim's identity is not established at the time of diagnosis of brain death and organ retrieval. The issue of identity should be addressed in future amendments to the Criminal Procedure Code to streamline and expedite the process.

\section{Brain death}

There are three types of brain death, they are cortical death, brain stem death and whole brain death. ${ }^{28}$

Cortical death is better known as a vegetative state, where person can no longer be recognized as a "social man". ${ }^{29}$ If the vegetative state continues for more than 1 month it is known as the persistent vegetative state. However, the Sri Lankan law does not identify the persistent vegetative state as a specific entity and medical professionals treat the person as in a deeply comatose state. ${ }^{30}$

In the United States, The uniform determination of death Act , 1981 has defined death as either irreversible cessation of circulatory / respiratory function or irreversible cessation of all functions of the entire brain, including the brain stem. ${ }^{31}$ In Sri Lanka, The Transplantation of Human Tissues Act (No.48 of 1987)section 15, has defined death as irreversible cessation of all functions of the brain, which may be determined by the prolonged absence of spontaneous circulatory and respiratory functions which shall be determined by any means recognized by the ordinary standards of current medical practice. Medical professionals frequently encounter ethical and legal dilemmas when determining the time of death of eligible organ donors on artificial life support.

\section{Certification of brain death}

In United Kingdom, clinical diagnosis of brain stem death can be made by clinical testing alone by two medical practitioners holding full GMC registration for more than 5 years, one of whom should be a Consultant, sufficient for diagnosis of brain stem death as long as they are competent to undertake the tests, experienced in interpreting the results, and should be independent of the transplant team. ${ }^{28}$

In India, for the clinical diagnosis of brain death, two certificates are required 6 hours apart from doctors and two of these have to be doctors nominated by the appropriate authority of the government with one of the two being an expert in the field of neurology. ${ }^{32}$

However in Sri Lanka, clinical diagnosis of brain death can be made without a consultant or an expert in the field of neurology but as in UK, and in India ${ }^{33}$ the medical practitioner who is certifying the death is independent of the transplantation team. ${ }^{13}$ According to the DGHs circulars on organ Transplantation, certification of brain death for patients on ventilatory support systems is made by two doctors(Anesthetist/ Medical Officer, Intensive Care Unit), independently twice each, one of whom at least should be a senior doctor 5 years after qualification, preferably with a specialist qualification.

Sri Lanka is a country where most hospitals have one or two ICUs with a single anesthetist in charge of the ICU and surgical theatre. The anaesthetist is also part of the transplantation team. However, legally, the diagnosis of brain death should be made by the two doctors who are independent of the transplant team. Therefore it is timely that we adopt criteria used in UK and India to make amendments to the health circulars for 
those involved in diagnosis of brain death especially for transplantation purposes.

\section{Circulatory death (non-heart-beating donation)}

Organ donation after cessation of cardiac pump activity is referred to as non-heartbeating organ donation (NHBD). NHBD donors can be neurologically intact; they do not fulfill the brain death criteria prior to cessation of cardiac pump activity. ${ }^{34}$ The number of NHBDs are gradually increasing and represents around $11.3 \%$ cadaveric donation in UK. ${ }^{35}$ Many countries are following NHBD and primarily strict to the Maastricht protocol. ${ }^{36}$

The fundamental problem with NHBD is warm ischaemia, which may lead to suboptimal function of transplanted organ. Steps need to be taken for organ protection by adopting strategies to keep warm ischaemia times as short as possible which will lead to more successful outcomes from non-heart-beating donors. ${ }^{37}$

Solid organs suitable for transplantation from non-heart beating donors include kidneys, livers and lungs. ${ }^{32}$

The Sri Lankan Transplantation of Human Tissue act (No.48 of 1987) section 15 defines death as irreversible cessation of all function of the brain and therefore provides no opportunity harvesting organs from NHBD. Therefore it is timely that this be addressed in the near future.

\section{Consent for adult organ donation}

In Sri Lanka, any person who is alive and above 21 years of age can give consent to the donation of his body, organs or tissue, which will be effective after his death. ${ }^{13}$

The next of kin of any deceased person, who is above 21 years of age, may give consent for removal of the body, any part thereof or any tissues of deceased person who has not given prior consent for organ donation but, had not expressed any contrary intention at any time during his life. ${ }^{13}$

\section{Prisoners}

Any part or any tissue can be removed from a prisoner who dies inside a prison, if the prisoner had given consent for donation effective upon death; and had not revoked such consent.

\section{Organ donation in children}

Around $81 \%$ of childhood deaths occur due to accidental causes in Sri Lanka. Among them, the most frequent cause of death which is drowning, accounts for $33 \%$ of childhood deaths. ${ }^{38}$

Anencephaly is a congenital condition where the infant is often stillborn. However a small percentage may remain alive for days to months. These infants do not meet the existing brain death criteria. Therefore obtaining transplants from such cases would raise numerous ethical and legal issues. ${ }^{39}$ According to section 306 of the penal code of Sri Lanka, there is strict prohibition on abortion, with the only exception being to save the life of mother. In February 2013 suggestions to amend the penal code section 306 of 1995 were made in order to relax the strict prohibition on the termination of pregnancy in cases of congenital abnormalities incompatible with life /serious foetal impairment. ${ }^{40}$ However, this did not become a reality. The incidence of anencephaly births during the year of 2005were 292in Sri Lanka ,15662 in India 886 in UK and 4318 in USA. ${ }^{41}$ In United States one in every 4859 babies born are anencephalic and 859 cases were reported during the year of $2004-2006 .{ }^{42}$ They are potential heart, liver and kidney donors. ${ }^{43,44}$

On the death of any child, both parents or in the absence or incapacity of one parent, the other parent or in the absent of both parents, the guardian of such child can give consent in writing for the removal of the body or any part or any tissues. ${ }^{13}$ 


\section{Organ storage and preservation of tissues}

With the shortage of organs available for transplantation, there is an urgency for a better use of available organs. Organ preservation is crucial in the transplant process. The main goal in organ preservation is to maintain the function of the organ and tissue during storage so that the graft will function at re-perfusion. ${ }^{34}$

Where a tissue is removed from a human body under the Transplantation Of Human Tissues Act it shall be the duty of the prescribed technician who removes it from the body to preserve it in any such place and under such conditions as may, from time to time, be prescribed, until it is duly transplanted: However, the provisions of this section shall not apply to any case where the medical practitioner performing the transplantation considersit fit to perform the removal of any tissue from a body and the transplantation of same immediately, without sending it to any such place of preservation. ${ }^{13}$

It is also important to maintain a proper register for donors and recipients, maintain confidentiality between both parties and take adequate precautions in disposal of unused organs and tissues.

\section{Disclosure of information}

According to the section 18 of the Transplantation of Human Tissues Act, no person shall disclose or give to any other person any information or document (except where legally required to do so) the identity of any person. ${ }^{13}$

1. who has given or refused to give a consent under THT Act; or

2. with respect to whom a consent has been given under THT Act; or

3. into whose body a tissue has been, is being or may be transplanted, may become publicly known.
Further any person acting in contravention of subsection (1) section 18 of THT shall be guilty of an offence and conviction after summary trial before a Magistrate, be liable to imprisonment of either description for a period not exceeding one year or to a fine not exceeding one thousand rupees or to both such imprisonment and fine. ${ }^{13}$

\section{Media}

The mass media can both be useful in promoting donations as well as be potentially dangerous in adversely affecting organ donation. Any negative broadcast concerning such delicate matters as brain death, organ trafficking, or unfairness in the access to transplantation may adversely influence the attitude of the public towards organ donation. ${ }^{37} \mathrm{Without}$ the support of the general public and their willingness to donate there would be no organs to transplant. ${ }^{37}$ The media can be used to reach the public and educate them through periodic meetings of journalists, experts in communication and opinion leaders in transplantation. ${ }^{37}$

\section{Summary}

It is clear that there is a necessity to strengthen the organ donation and transplantation program in Sri Lanka. It can be achieved through effective coordination at national and local level under the direct supervision of the ministry of health with help of other stake holders, under the guidance of the legal fraternity. Awareness programs regarding organ donation among the general public of all age groups is essential to cater to the future need. The media can be used very effectively under an ethical and legal framework to overcome the organ shortage.

Reviewing of the program intermittently to identify issues and introducing changes to health circulars and legal framework with help of stakeholders is essential for an effective program. 


\section{REFERENCES}

1. Matesanz R, Domínguez-Gil B, Coll E, Mahíllo B, Marazuela R. How Spain reached 40 deceased organ donors per million population. American Journal of Transplantation. 2017;17(6):1447-54. doi:10.1001/jama.1989.03420120111036

2. Organ Donation and Transplantation Activities 2014 [Internet]. The Global Observatory on Donation and Transplantation (GODT). World Health Organization. (2016 april updated). [cited 10 Jul 2018]. Available from: http://www.transplant-observatory.org/ datareports-2014/

3. Sulania A, Sachdeva S, Jha D, Kaur D, Sachdeva R. Organ donation and transplantation: An updated overview. MAMC Journal of Medical Sciences.2016;2:18-27. DOI: $10.4103 / 2394-7438.174832$

4. Nushka Nafeel. CARE to SHARE : Organ donation, saving lives. 2017, feb,2. [cited 10 jul 2018]. Daily News [Internet]. Available from:

http://www.dailynews.lk/2017/02/02/feature s/106424/care-share-organ-donation-savinglives

5. Deceased organ donors in United States exceeded 10,000 for first time in 2017. UNOS. 2018 Jan 09. [cited 10 Jul 2018]. Available from: https://unos.org/deceased-organ-donors-inunited-states-exceeded-10000-for-first-timein-2017/

6. Living donation [Internet]. Organ Donation. [cited 10 Jul 2018]. Available from: https://www.organdonation.nhs.uk/aboutdonation/what-is-living-donation/

7. Mayo clinic staff. Living-donor transplant. Mayo Foundation for Medical Education and Research (MFMER). 2018. [cited $10 \mathrm{Jul}$ 2018]. Available from: www.mayoclinic.org/tests-procedures/ living-donor-transplant/about/pac-20384787

8. The Living Donation Process.U.S. Government Information on Organ Donation and Transplantation. HRSA. 2018. [cited 10 july 2018. Available from: https://organdonor.gov/about/ process/living-donation.html

9. Thomas CP, Mansilla MA, Sompallae R, Mason SO, Nishimura CJ, Kimble MJ, Campbell CA, Kwitek AE, Darbro BW, Stewart ZA, Smith RJ. Screening of living kidney donors for genetic diseases using a comprehensive genetic testing strategy. American Journal of Transplantation. 2017 Feb;17(2):401-10. https://doi.org/10.1111/ajt.13970

10. Spital A. Justification of living-organ donation requires benefit for the donor that balances the risk: Commentary on Ross et al. Transplantation. 2002 Aug 15;74(3):4234.

11. De Alwis LB. Lecture notes in forensic medicine Vol. II forensic pathology and forensic science. Colombo: Primal Printers. 2008;2:172-3.

12. Capron AM, Kass LR. A statutory definition of the standards for determining human death: An appraisal and a proposal. University of Pennsylvania Law Review. 1972 Nov 1;121(1):87-118.

13. Transplantation Of Human Tissues Act (No. 48 of 1987), Legislative enactments, Sri Lanka

14. Adam R, Karam V, Delvart V, O’Grady J, Mirza D, Klempnauer J, Castaing D, Neuhaus P, Jamieson N, Salizzoni M, Pollard S. Evolution of indications and results of liver transplantation in Europe. A report from the European Liver Transplant Registry (ELTR). Journal of hepatology. 2012 Sep 1;57(3):675-88.

DOI: $10.2307 / 3311148$

15. Cuervas-Mons V, de la Rosa G, Pardo F, San Juan F, Valdivieso A. Activity and results of liver transplantation in Spain during 1984-2012. Analysis of the Spanish Liver Transplant Registry. Medicina Clínica (English Edition). 2015 Apr 20;144(8):33747. https://doi.org/10.1016/j.medcle.2015.11.01 1 
16. Feng S, Goodrich NP, Bragg-Gresham JL, Dykstra DM, Punch JD, DebRoy MA, Greenstein SM, Merion RM. Characteristics associated with liver graft failure: the concept of a donor risk index. American Journal of Transplantation. 2006 Apr;6(4):783-90.

https://doi.org/10.1111/j.1600-

6143.2006.01242.x

17. Han JH, You YK, Na GH, Kim EY, Lee SH, Hong TH, Kim DG. Outcomes of living donor liver transplantation using elderly donors. Annals of surgical treatment and research. 2014 Apr 1;86(4):184-91. https://doi.org/10.4174/astr.2014.86.4.184

18. Akoh JA, Mathuram Thiyagarajan U. Renal transplantation from elderly living donors. Journal of transplantation. 2013 Sep $12 ; 2013$. http://dx.doi.org/10.1155/2013/475964

19. Moreso F, Serón D, Gil-Vernet S, Riera L, Fulladosa X, Ramos R, Alsina J, Grinyó JM. Donor age and delayed graft function as predictors of renal allograft survival in rejection-free patients. Nephrology, dialysis, transplantation: official publication of the European Dialysis and Transplant Association-European Renal Association. 1999 Apr 1;14(4):930-5.

https://doi.org/10.1093/ndt/14.4.930

20. Woo YM, Gill JS, Johnson N, Pereira BJ, Hariharan S. The advanced age deceased kidney donor: current outcomes and future opportunities. Kidney international. 2005 Jun 1;67(6):2407-14.

https://doi.org/10.1111/j.15231755.2005.00348.x

21. Abecassis M, Bridges ND, Clancy CJ, Dew MA, Eldadah B, Englesbe MJ, Flessner MF, Frank JC, Friedewald J, Gill J, Gries C. Solid-organ transplantation in older adults: current status and future research. American Journal of Transplantation. 2012 Oct;12(10):2608-22.

https://doi.org/10.1111/j.1600-

6143.2012.04245.x

22. Sawhney C, Kaur M, Lalwani S, Gupta B, Balakrishnan I, Vij A. Organ retrieval and banking in brain dead trauma patients: Our experience at level-1 trauma centre and current views. Indian journal of anaesthesia. 2013 May;57(3):241. https://dx.doi.org/10.4103\%2F00195049.115599

23. Statistics. Ministry of Transport and Civil Aviation, Sri Lanka. 2018 [cited 10 Jul 2018]. Available from: http://transport.gov.lk/web/index.php?option $=$ com_content $\&$ view $=$ article $\&$ id $=279 \&$ Item $\mathrm{id}=171 \&$ lang=en

24. Crime Statistics [Internet]. Sri Lanka Police. [cited 10 Jul 2018]. Available from: https://www.police.lk/images/others/crime_t rends/2016/grave_crime\%20.pdf

25. Suicide in Sri Lanka: Understanding the Crisis [Internet]. Forum for suicide and culture research. [cited 10 Jul 2018]. Available from:

https://suicideandculture.wordpress.com/201 4/05/28/suicide-in-sri-lanka-understandingthe-crisis/

26. Rathnaweera RHAI.Trends of homicides in Galle-Sri Lanka, Medico-Legal Journal of Sri Lanka. 2016;3(1):16-21.

27. Code Of Criminal Procedure Act (No. 15 of 1979) - Sect 367

28. Walallawita LD. Brainstem death and organ donation. Sri Lankan Journal of Anaesthesiology. 2009;10:17(2).

29. Brody BA. Ethical questions raised by the persistent vegetative patient. Hastings Center Report. 1988 Feb 3;18(1):33-7.

https://doi.org/10.2307/3562015

30. Rohan RP. A brain death: concepts and confusions among medical experts, legal authorities and general public in Sri Lanka. Galle Medical Journal. 2008 Sep;13(1):49.

31. http://en.wikipedia.org/wiki/Uniform_Deter mination_of_Death_Act

32. Shroff S. Legal and ethical aspects of organ donation and transplantation. Indian journal of urology: IJU: journal of the Urological Society of India. $2009 \mathrm{Jul} ; 25(3): 348$. https://dx.doi.org/10.4103\%2F09701591.56203 
33. The Transplantation of Human Organs and Tissues Act (Act No 42 of 1994 ). Legislative enactments, India

34. Guibert EE, Petrenko AY, Balaban CL, Somov AY, Rodriguez JV, Fuller BJ. Organ preservation: current concepts and new strategies for the next decade. Transfusion Medicine and Hemotherapy. 2011;38(2):125-42. https://doi.org/10.1159/000327033

35. Brook NR, Waller JR, Richardson AC, Andrew Bradley J, Andrews PA, Koffman G, Gok M, Talbot D, Nicholson ML. A report on the activity and clinical outcomes of renal non-heart beating donor transplantation in the United Kingdom. Clinical transplantation. 2004 Dec;18(6):627-33. https://doi.org/10.1111/j.13990012.2004.00287.x

36. Daemen JW, Kootstra G, Wijnen RM, Yin M, Heineman E. Nonheart-beating donors: the Maastricht experience. Clinical transplants. 1994:303-16.

37. Ridley S, Bonner S, Bray K, Falvey S, Mackay J, Manara A. UK guidance for nonheart-beating donation. British journal of anaesthesia. 2005 Sep 23;95(5):592-5. https://doi.org/10.1093/bja/aei235

38. Kitulwatte ID, Edirisinghe PA. Study on unnatural childhood deaths presented to North Colombo teaching hospital, Sri Lanka. Medicine, Science and the Law. 2014 Apr;54(2):74-7. doi: $10.1177 / 0025802413491249$
39. Ahmad F. Anencephalic infants as organ donors: beware the slippery slope. CMAJ: Canadian Medical Association Journal. 1992 Jan 15;146(2):236.

40. MEDICAL TERMINATION OF PREGNANCY - PROPOSALS OF THE LAW COMMISSION OF SRI LANKA. 2013. [cited $10 \mathrm{Jul}$ 2018]. Available from: http://lawcom.gov.lk/web/images/stories/rep orts/medical_termination_of_pregnancy_pro posals_of_the_law_commission_of_sri_lank a.pdf

41. Statistics by Country for Anencephaly. Updated 2010. [cited 10 Jul 2018]. Available from:

http://www.cureresearch.com/a/anencephaly /stats-country.htm

42. Birth defects. Centers for Disease Control and Prevention. US department of health and services. Updated 2018. [cited $10 \mathrm{Jul}$ 2018]. Available from: https://www.cdc.gov/ncbddd/birthdefects/da ta.html.

43. Medical Task Force on Anencephaly*. The infant with anencephaly. New England Journal of Medicine. 1990 Mar 8;322(10):669-74.

DOI: 10.1056/NEJM199003083221006'

44. Shewmon DA, Capron AM, Peacock WJ, Schulman BL. The use of anencephalic infants as organ sources: a critique. JAMA. 1989 Mar 24;261(12):1773-81. doi:10.1001/jama.1989.03420120111036 